\title{
Preliminary results of the recent excavation of a radiolarite mine area and its surroundings in Sedmerovec
}

\author{
Ivan Cheben ${ }^{1}$, Michal Cheben $^{2}$, Adrián Nemergut ${ }^{3}$
}

Abstract

Kivonat

Keywords

Kulcsszavak

Authors • Szerzők

Cite as • hivatkozás

Article history •

Kézirat történet

Copyright • Jogok

(c) (i) $(5)$
The article deals with the archaeological investigation of Sedmerovec-Kašnák and Sedmerovec-Podjamie sites from 2016. In Sedmerovec-Kašnák mine area, archaeological investigations were carried out in the western half of the pit. Unfortunately, no archaeological material was found. During the surface survey and archaeological excavation in Sedmerovec-Podjamie site, a rich collection of a lithic industry was obtained. Important are rhomboids most probably from the late Mesolithic. A portion of the artifacts belongs to the Neolithic and Eneolithic.

Előzetes jelentés egy radiolarit nyersanyag-kitermelő hely és környezete feltárásáról Sedmerovecben A közlemény Sedmerovec-Kašnák és Sedmerovec-Podjamie 2016-os ásatásával foglalkozik. A SedmerovecKašnák-i bányaterületen a fejtő nyugati felében végeztünk feltárásokat, itt régészeti anyag sajnos nem került elő. Sedmerovec-Podjamie területén azonban a terepbejárás és az ásatásaok gazdag pattintott kő leletanyaggal szolgáltak, melyek közül kiemelendő a rombuszok jelenléte, melyek valószínúleg késő mezolitikus korúak. A leletek egy része az újkőkor és a rézkor időszakaira keltezhető.

Slovakia, White Carpathians, sources of radiolarites, mining areas, lithic industry, late Mesolithic, Neolithic, Eneolithic Szlovákia, Fehér-Kárpátok, radiolarit források, bányaterületek, kôipar, késố mezolitikum, neolitikum, rézkor

1,2,3 - Institute of Archaeology Slovak Academy of Sciences, Akademická 2, 94921 Nitra, Slovak Republic. 1 - ivan. cheben@savba.sk, 2 -nraumche@savba.sk, 3 - adrian.nemergut@savba.sk

Cheben, I., Cheben, M., Nemergut, A. (2017) Preliminary results of the recent excavation of a radiolarite mine area and its surroundings in Sedmerovec. Litikum 5: 5-11. https://doi.org/10.23898/litikuma0020

Received | Érkezés: 2016. 11. 10. Accepted | Elfogadás: 2016. 11. 15. Published | Közzététel: 2017. 01. 07.

(C) 2017. Cheben, Cheben, Nemergut. This is an open-access article distributed under the terms of the Creative Commons Attribution License, which permits unrestricted use, distribution, and reproduction in any medium, provided the original author and source are credited. | Ez egy nyílt hozzáférésú publikáció, amit a Creative Commons 4.0 licensze véd. A termék szabadon használható, terjeszthető és sokszorosítható az eredeti szerző és forrás megjelölése mellett.
In 2016, an archaeological investigation in Sedmerovec was carried out at Podjamie and Kašnák sites. It followed a surface survey from 2015 when several sites in microregion of Nemšová - Červený Kameň were visited (Cheben et al., in print). The aim of the investigation in 2016 was to detect the shape and course of one of the pinges (mine slumps) at the Kašnák site, or possibly, to obtain suitable archaeological material for dating. At the site of Podjamie, the investigation focused on determination of the site's size, verification of stratigraphic situation and obtaining chronologically sensitive artifacts or suitable organic material for radiocarbon dating.

The oldest collected finds from Sedmerovec were published and classified by J. Bárta $(1965,123)$ to the Gravettian. I. Vlkolinská, L'. Illášová and J. Hunka $(1998,170)$ carried out a surface survey at several sites in Pruské and Sedmerovec in 1996 as part of a survey along the course of D1 motorway. I. Cheben and M. Cheben (2010) have dealt with the topic of the use of primary sources of radiolarites in the territory of the Central Váh river basin more intensely in the last eleven years. In this period, they carried out several surface surveys focused on detection of primary sources of radiolarite as well as trench investigation in exploitation pits in Vršatské Podhradie and Krivoklát. In the early 1990s, several surveys focused on detection of primary sources of radiolarite were conducted in the central part of the White Carpathians (Cheben et al. 1995; Cheben, Illášová, Hromada 1996). A surface survey in Sedmerovce was also led by O. Žaár, P. Schreiber, L. Štec and L. Blašková in 2009 (Žaár et al. 2013). The prospection of I. Cheben, M. Cheben, A. Nemergut and M. Soják in 2015 was focused to primary sources of radiolarites, mining areas and archeological sites located in the central Váh region (Cheben et al., in print).

\section{Sedmerovec-Kašnák}

An outcrop of crinoidal limestone belonging to the Czorsztyn succession was detected on the distinct loess ridge in the Váh river valley, in its western end in the foothills of the klippen belt (Mello 2011). It probably contained exclusively nodules (concretions) of radiolarite. This site is situated on the hilltop at the site of Kašnák, approximately $1 \mathrm{~km}$ northeast of the village of Sedmerovec (Fig. 1). Its altitude is $360 \mathrm{~m}$. Radiolarite raw material outcrops on a distinct terrain elevation where several sunken circular pits of various sizes were 


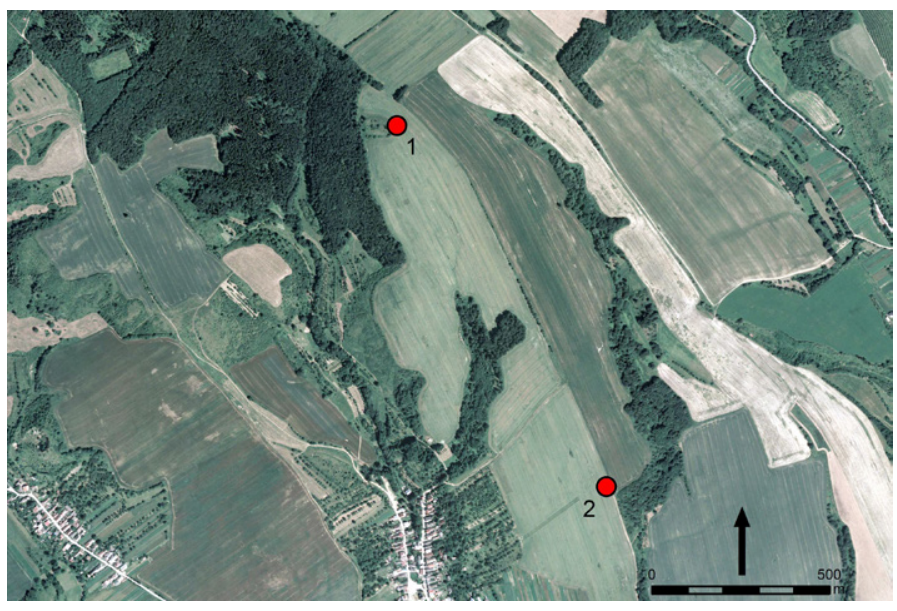

Figure 1. Map of sites. 1 - Sedmerovec-Kašnák; 2 - SedmerovecPodjamie. Author: A. Nemergut. // 1. ábra. A lelőhelyek térképe. 1 Sedmerovec-Kašnák; 2 - Sedmerovec-Podjamie. Ábra: A. Nemergut.

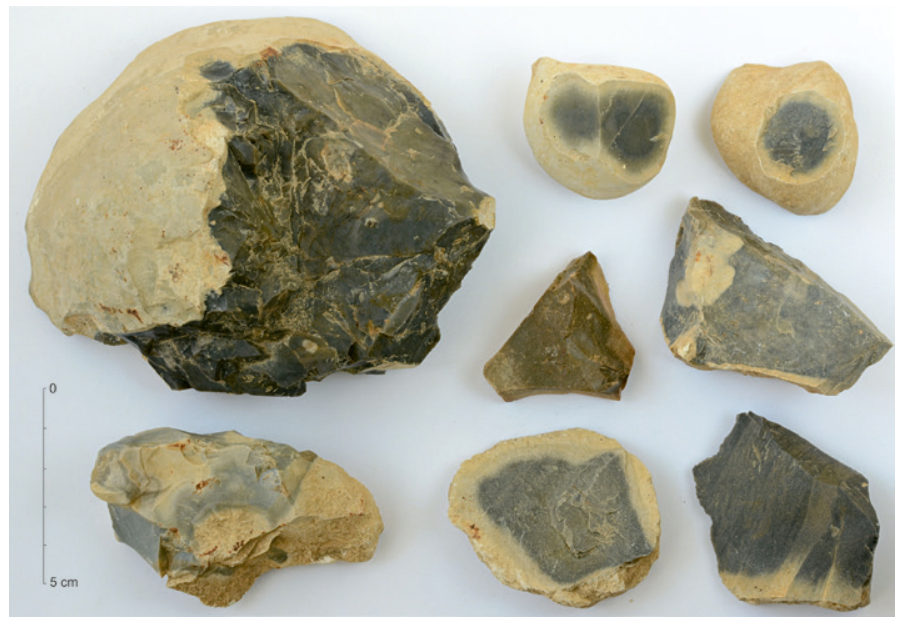

Figure 3. Sedmerovec-Kašnák. Radiolarite of the Kašnák type. Photo by: A. Nemergut. // 3. ábra. SedmerovecKašnák, Kašnák típusú radiolarit. Fotó: A. Nemergut.

found (Fig. 2). The western part of the hill was partly destroyed when a limestone quarry was founded. The depressions are distributed in two rows over the stepped or terraced slope covered with grass and partly with trees and shrubs. The immediate surroundings of the mine area are now intensely used for farming, which enables surface surveys to obtain a large number of examples of the raw material itself as well as chipped industry. As for color varieties, light grey, black, grey-yellow to beige radiolarites with typically rough light yellow to beige limy crust are represented (Fig. 3). The crust is 1 to $1.5 \mathrm{~cm}$ thick. Alternating dark and light layers of silicite matter can often be observed on the nodules. Such colored varieties of radiolarite and the fact that they have crust have not been discovered within the studied area of this part of the klippen belt before. On the basis of these facts, this color variety of radiolarite was named radiolarite of the Kašnák type, since this raw material is distinguishable from common color varieties at prehistoric settlements. This radiolarite raw material appeared for instance in the collection of chipped lithic industry from the paleolithic site in Moravany nad Váhom-Dlhá (Nemergut, Cheben, Gregor 2012). Its use is also documented in other collections of

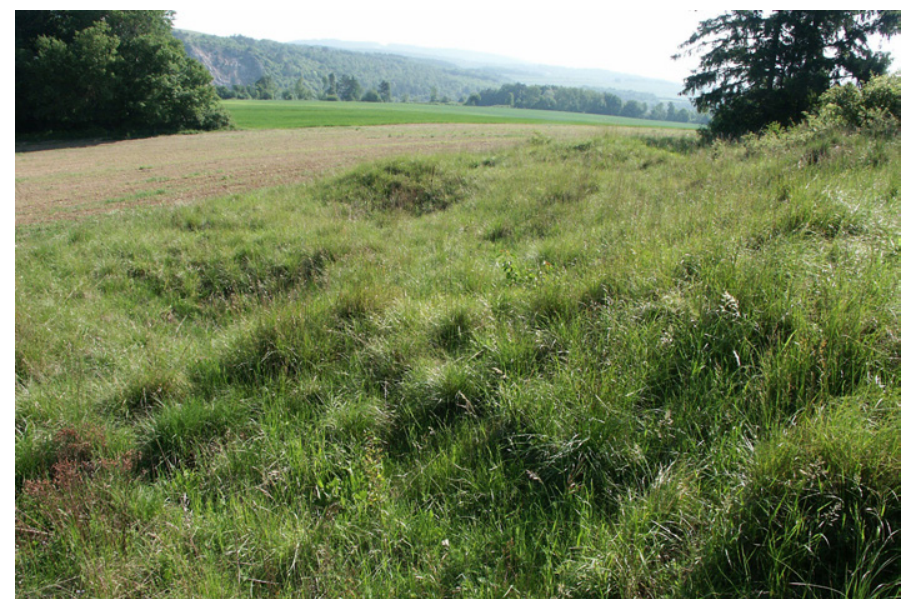

Figure 2. Sedmerovec-Kašnák. View of the site. Photo by: M. Cheben. // 2. ábra. Sedmerovec-Kašnák. Fotó: M. Cheben.

chipped stone industries from the prehistoric settlements in Sedmerovec-Nad cestou, Podskalčie, Podjamie and Galková sites (Cheben et al., in print).

Before the investigation of the selected pinge itself, a geophysical survey with georadar was carried out; nevertheless, it did not bring the expected results. The georadar did not detect the pinge's shaft. The investigated pinge was funnel-shaped with the diameter of $6 \mathrm{~m}$. The archaeological excavation was carried out in the western half of the pinge. The gradual deepening of the backfill layers started to uncover the bedrock in the north and west. The upper part of the backfill was made of humus soil; a debris layer consisting of the parent rock fragments of different sizes appeared below it. It reached down to the bedrock. Two layers of black clay soil were detected in the debris (Fig. 4). The first layer was detected approx. in the middle of the profile, the second one was found above the bedrock. They are probably two soil horizons. Their presence suggests that the pinge was open for a rather long time after it had been abandoned (i. e. it was not filled back immediately). Later, the pinge was probably partly filled with attle from one of the nearby pinges and then, it was abandoned again for some time. Bedrock was detected approx. $1.3 \mathrm{~m}$ deep. The pinge's bottom was uneven, with two distinct depressions situated approx. in the middle. The northern and western walls of the pinge were made of crinoidal limestone layers leaning northwards at an angle of $50-60^{\circ}$. The southern wall (towards the hill) was made of one massive limestone plate.

No archaeological material (chipped lithic industry, antler industry, plant remains) or radiolarite raw material was found in the pinge's backfill.

\section{Sedmerovec-Podjamie}

The site is situated on a terrace slightly sloping town southeastwards, at the site of Podjamie, with a great view of the Váh floodplain. It is approximately $500 \mathrm{~m}$ northeastwards from the residential area of Sedmerovec, at the altitude of approximately $300 \mathrm{~m}$ (Fig. 1). 


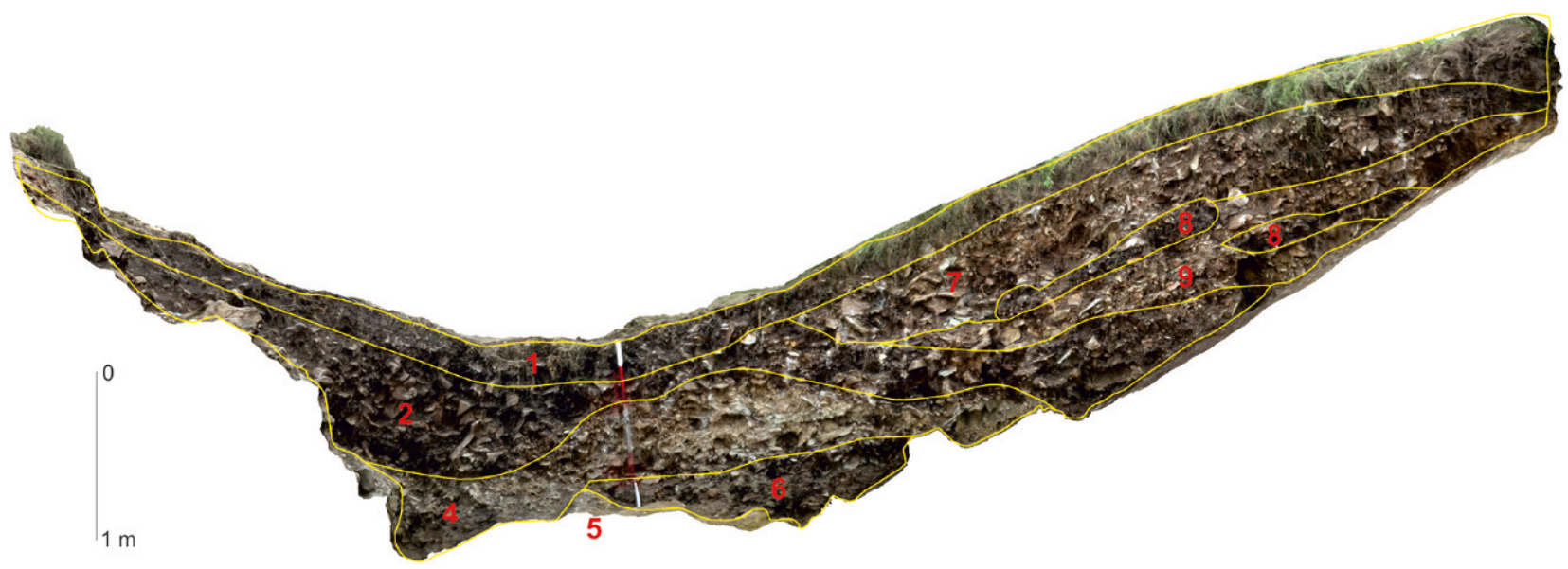

Figure 4. Sedmerovec-Kašnák. Southeastern profile. 1 - humus soil; 2 - light orange layer of debris (parent rock mixed with soil); 3 - debris layer with fine material; 4 - bedrock; 5 - dark grey soil-clay layer with fragments (up to $10 \mathrm{~cm}$ ) of underlying rock; 6 - grey-yellow debris layer (parent rock mixed with soil); 7 - dark grey to black soil-clay layer with fragments (up to $5 \mathrm{~cm}$ ) of underlying rock; 8 - grey-yellow layer of fine debris (parent rock mixed with soil). Illustration by: B. Balžan, M. Cheben. // 4. ábra. Sedmerovec-Kašnák, délkeleti metszet. 1 - humusz; 2 - világos narancssárga törmelékes réteg (anyakőzet és talaj); 3 - finomabb törmelékes réteg; 4 - anyakőzet; 5 - sötétszürke agyagos talajréteg max. $10 \mathrm{~cm}$ méretű kőtörmelékkel; 6 - szürke-sárga törmelékes réteg (anyakőzet és talaj); 7 - sötétszürke-fekete agyagos talajréteg max. $5 \mathrm{~cm}$ méretű kőtörmelékkel; 8 - szürke-sárga finomabb törmelékes réteg (anyakőzet és talaj). Illusztráció: B. Balžan, M. Cheben.

The investigation was divided into three stages. In the first stage, a surface prospection was carried out. Its goal was to detect the size of the site and obtain material for a more precise chronological classification of settlement. In the second stage, a geophysical survey with magnetometer was conducted, detecting several anomalies (Fig. 5). In the third stage, ten trenches were excavated. Trenches 1-5 were arranged along one axis, $10 \mathrm{~m}$ from each other, along with the field track crossing the site. Each trench's size was $1 \times 1 \mathrm{~m}$. Trench 3 was extended to $2 \times 3 \mathrm{~m}$, i. e. five more trenches with sizes of $1 \times 1$ $\mathrm{m}$. Sediments from the trenches were sifted through a sieve with meshes of $2 \times 2 \mathrm{~mm}$.

In relation to the stratigraphic situation, a layer of topsoil was detected in trench 10; it contained archaeological material. Under the topsoil layer, a sterile layer of brown-yellow clay was found. In trenches 1-9, topsoil layers were also detected, covering a light grey-brown layer of earth containing, similarly to the topsoil, some finds of lithic industry and sherds of pottery. Moreover, in trenches 4-6, a pit of irregular oval shape, with the rugged bottom, was detected (Fig. 6). Lithic artifacts and pottery finds were found in the feature.

1300 pieces of chipped stone industry in total obtained in a surface collection. Finds contain 18 pieces of radiolarite raw material with traces of manipulation, 31 single-platform cores of radiolarite, mostly flat, carénoid or prismatic forms, exploited from one side only, with the original surface on other sides, or only struck several times. Only one core was modified with crested blades (Fig. 10: 2). There was one pyramid-shaped core with parallel exploitation along all edges (Fig. 9: 6). Furthermore, 13 core residues and 55 core fragments were identified; 53 of them were made of radiolarite and 2 were made of burned silicite. As for blades, bladelets and their fragments, 154 examples were made of radiolarite. 27 examples as complete pieces ( 7 of them were crested) were recognized. 128 fragments altogether were obtained. The collection contains 303 flakes, 302 of them are obtained from

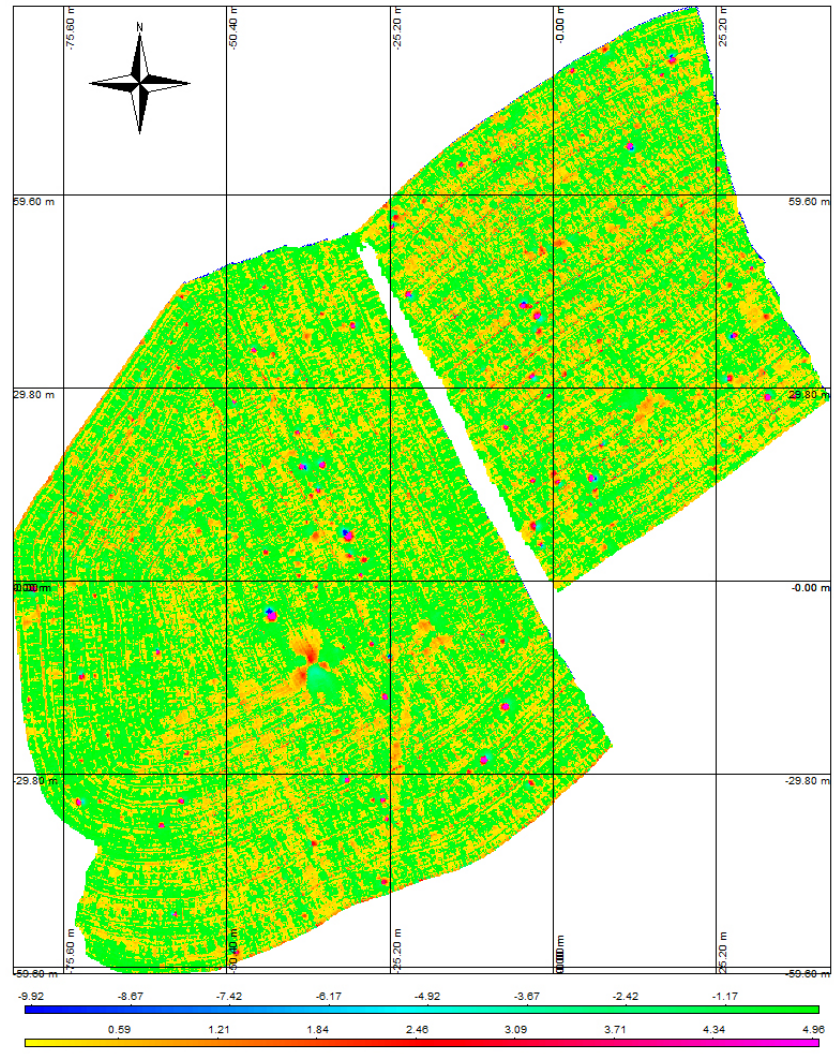

Figure 5. Sedmerovec-Podjamie. The map of anomalies of the geophysical survey with a magnetometer. Author: M. Cheben. // 5. ábra. Sedmerovec-Podjamie, a magnetométeres felmérés által kimutatott anomáliák térképe. Ábra: M. Cheben.

radiolarite (three examples were burned), one is from siliceous sandstone. The most numerous group comprises flake fragments and small flakes - 692 radiolarite, 16 burned radiolarite, 2 patinated silicite and 1 siliceous sandstone. A radiolarite burin spall was detected. Retouched tools, all made of radiolarite, include two end-scrapers, a two fragments of 


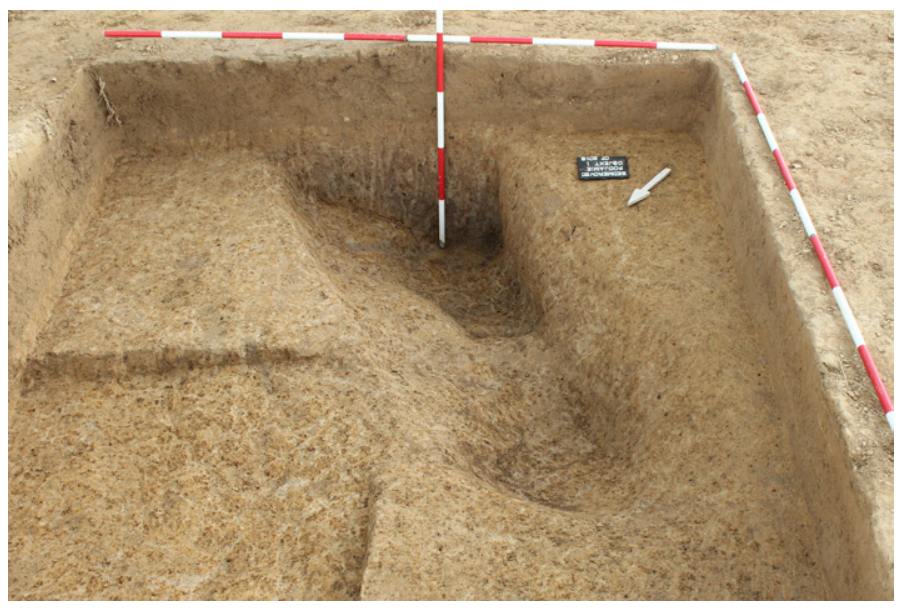

Figure 6. Sedmerovec-Podjamie. View of trenches 3, 5-9 and a pit 1. Photo by: M. Cheben. // 6. ábra. Sedmerovec-Podjamie, a 3, 5-9-es szelvények és az 1. sz. verem. Fotó: M. Cheben.

end-scrapers, a sickle blade, a fragment of a sickle blade (Fig. 10: 1), three fragments of truncated blades (probably sickle blades), three blades with local lateral retouch, three rhomboids - one from burned radiolarite (Fig. 9: 3) and two from unburnt radiolarite (Fig. 9: 4, 5), flakes with retouch and a fragment of a flake with retouch. The collection also includes a fragment of a polished artifact made of an undetermined raw material (Fig. 10: 4).

Finds from the topsoil in trenches 1-10 contain 1052 chipped lithic artifacts and pottery sherds. With the exception of one erratic silicite flake, all lithic finds were made of local radiolarite. Three pieces of raw material with traces of finishing, 25 cores - mostly flat, exploited on one side, with the original surface on a back side (Fig. 8: 2; 9: 1). The collection also contains nine core fragments, 194 blades, bladelets and their fragments, a tablet, 375 flakes, 442 fragments and small flakes. As for retouched tools, a notch, a truncated bladelet (Fig. 9: 2) and a retouched flake were obtained.

The archaeological material from the grey-brown soil layer (layer 1) under topsoil in trenches 1-9 comprises 749 examples of chipped lithic artifacts of radiolarite and pottery sherds. 19 cores were found; most of them are flat, exploited from one side only, with the original surface on the back side of the core (Fig. 7: 1). Carenoide cores are rare (Fig. 8: 1). The collection is completed with four core fragments, 130 blades, bladelets and their fragments, 342 flakes and 254 fragments and small flakes.

A collection of 210 pieces of chipped lithic industry made of radiolarite and fragments of pottery were obtained from the pit 1, trenches 4-6 (Fig. 11). Lithic artifacts include seven cores (Fig. 7: 2), 52 blades, bladelets and their fragments, 136 flakes and 15 fragments and small flakes. Fragment of a polished artifact with a drilled hole made of an undetermined raw material was also discovered in the pit (Fig. 10: 3).

\section{Discussion}

During the excavation of pinge in the Sedmerovec-Kašnák site, no waste mound made of the mining rock and no

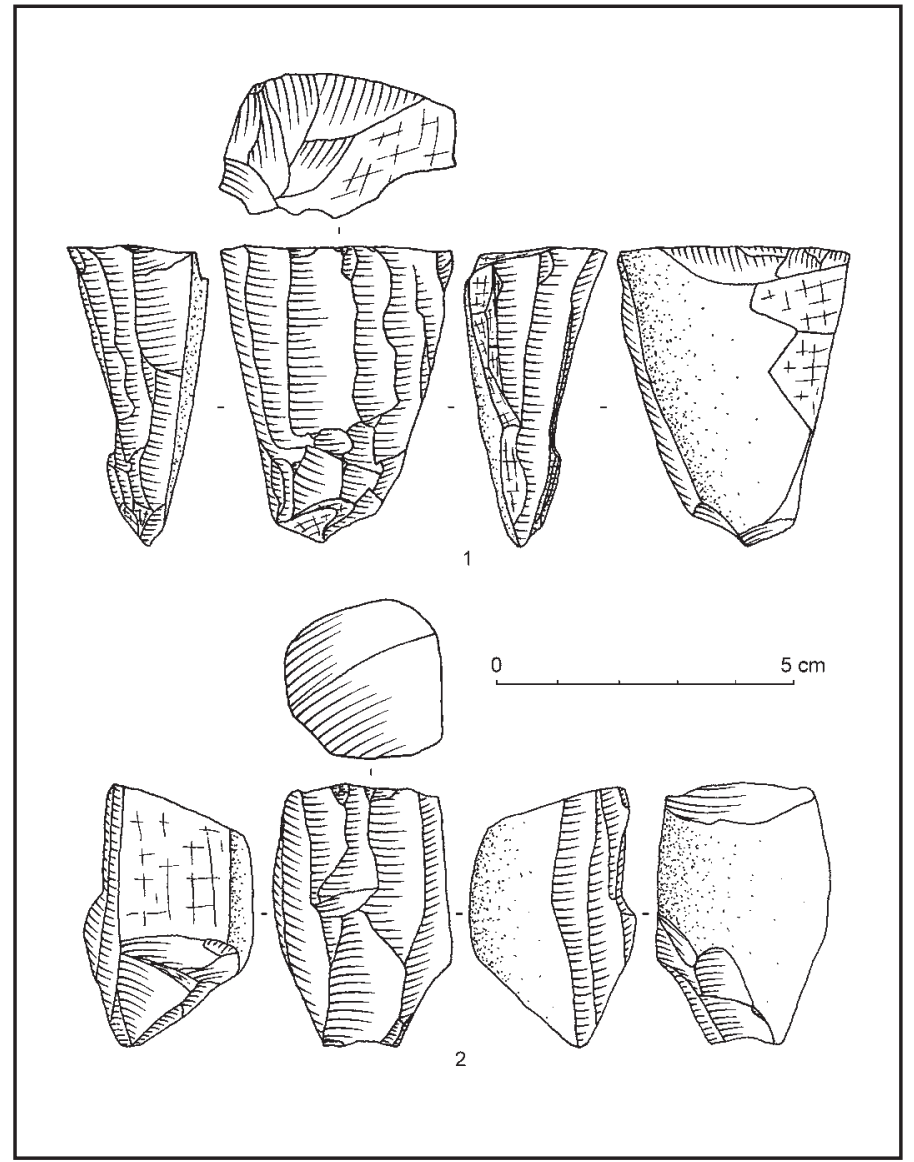

Figure 7. Sedmerovec-Podjamie. Cores. 1 - trench 3, layer 1; 2 trench 4, feature 1. 1,2 - radiolarite. Illustration by: A. Nemergut. // 7. ábra. Sedmerovec-Podjamie magkövek. 1 - 3. szelvény, 1. réteg; 2 - 4. szelvény, 1. jelenség. 1-2 - radiolarit. Illusztráció: A. Nemergut.

Figure 8 (facing page, upper left). Sedmerovec-Podjamie. Cores. 1 trench 5, layer 1; 2 - trench 6, topsoil. 1, 2 - radiolarite. Illustration by: A. Nemergut.

Figure 9 (facing page, upper right). Sedmerovec-Podjamie. Selected chipped stone industry. 1 - trench 9, topsoil; 2 - trench 10, topsoil; 3-6 collection. 1-6 - radiolarite. Illustration by: A. Nemergut.

Figure 10 (facing page, lower left). Sedmerovec-Podjamie. Selected chipped and polished stone industry. 1, 2, 4 - collection; 3 - trench 5, feature. 1,2 - radiolarite; 3, 4 - undetermined raw material. Illustration by: 1, 2 - A. Nemergut; 3, 4 - E. Bakytová.

Figure 11 (facing page, lower right). Sedmerovec-Podjamie. Selected pottery material. Illustration by: E. Bakytová. //

8. ábra (szemközti oldal, fent balra). Sedmerovec-Podjamie magkövek. 1 - 5. szelvény, 1 . réteg; 2 - 6. szelvény, felső réteg. 1, 2 - radiolarit. Illusztráció: $A$. Nemergut.

9. ábra (szemközti oldal, fent jobbra). Sedmerovec-Podjamie, válogatott leletek. 1 - 9. szelvény, felső réteg; 2 - 10. szelvény, felső réteg; 3-6 - felszíni gyüjtés. 1-6 - radiolarit. Illusztráció: A. Nemergut.

10. ábra (szemközti oldal, lent balra). Sedmerovec-Podjamie, válogatott leletek. 1, 2, 4 - felszíni gyüjtés; 3 - 5. szelvény, 1. jelenség. 1, 2 - radiolarit; 3, 4 - meghatározatlan nyersanyag. Illusztráció: 1, 2 - A. Nemergut; 3, 4 - E. Bakytová.

11. ábra (szemközti oldal, lent jobbra). Sedmerovec-Podjamie kerámiaanyag. Illusztráció: E. Bakytová

archaeological material was detected in 2016. Thus, dating of the pinge itself is not possible. From agricultural used surroundings, an assemblage of lithic artifacts contains mostly raw material blocks with traces of manipulation and waste from the blocks preparation were obtained in 2015. Tools from this surface survey are from Neolithic or Eneolithic (Cheben et al., in print). 

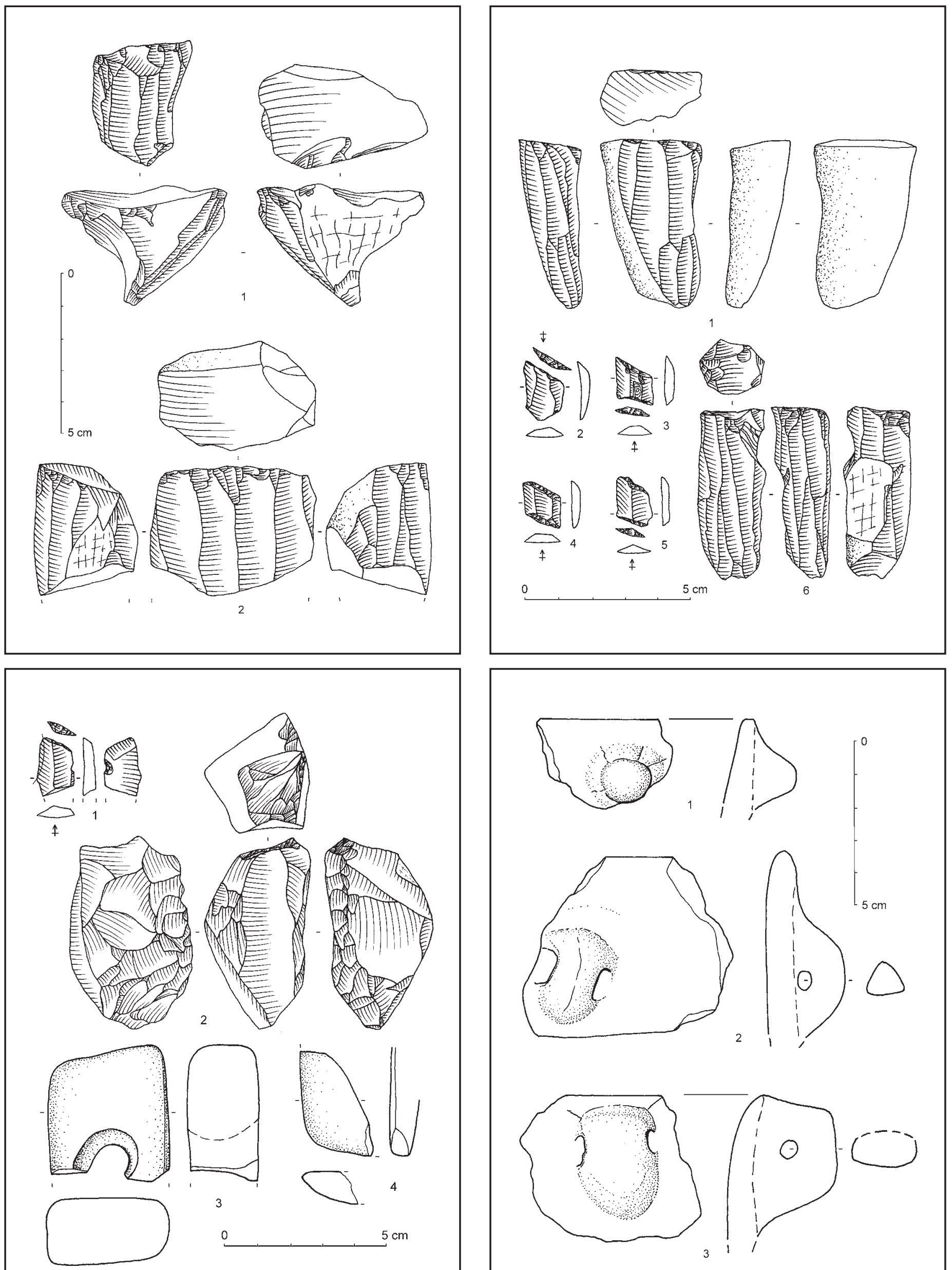
At Sedmerovec-Podjamie site, removed layers, pit, and a surface assemblage yielded a numerous lithic collection including pottery sherds also. In the lithic assemblage two groups were recognized. The first contains unipolar cores exploited on one side, with the original - cortex surface on a back side. These cores were used for producing of parallel edged blades and bladelets perhaps by using of indirect percussion (Fig. 7; 8; 9: 1). Similar production technique was described for example in late Mesolithic during the Castelnovian of northern Italy (Broglio, Kozłowski 1984; Gehlen 2009; 2010a, 417-445; 2010b, 612, 613; Perrin 2009, 518) and northeastern Adriatic (Gehlen 2010a, 395-401; Kozłowski, Kozłowski 1984), which is also connected with rhomboids, known from Sedmerovec-Podjamie site too (Fig. 9: 3-5). However, this production of parallel edged blades and bladelets and rhomboids as well continues to the early Neolithic (Gehlen 2010a, 445465; 2010b, 615; Perrin 2009, 518). Rhomboids during the early Neolithic are missing in lithic assemblages from Slovakia and surroundings (Kaczanowska, Kozłowski, Wasilewski 2015; Kaminská, Kaczanowska, Kozłowski 2008; Kozłowski, Nowak 2010). Relatively near analogies of parallel edged blades and bladelets is possible to find in the late Mesolithic Janislavice culture and early Neolithic Linear Pottery culture in the territory of Poland. On the base of comparative analysis of technology of blade production, there were two methods of preparation of percussion point recognized. In generally, Janislavician cores bear traces of abrasion of core processing edge, and „linear" cores have abraded but facetted edges (Wąs 2011, 22). Comparing of cores from Sedmerovec-Podjamie with mentioned conception could be problematic, for example, because of different raw material use (Sedmerovec - radiolarite, Poland - Chocolate and Świeciechów flint), missing of early Linear Neolithic pottery or unclear finding context. However, cores from Sedmerovec-Podjamie site may at first glance be attributed to both concepts. In the future, it would be good to compare the whole collection, including debitage with this conception, and also with close Sedmerovec-Nad Cestou site with the late Linear Pottery (Cheben et. al., in print). The second part of lithic assemblage of SedmerovecPodjamie Podjamie contain cores includes preparation by making a longitudinal crested ridge (Fig. 10: 2), sickle blade (Fig. 10: 1), polished artifacts as well (Fig. 10: 3, 4), which are connected with Neolithic or Eneolithic period, proved also by presence of pottery (Fig. 11), perhaps of Lengyel culture.

\section{Conclusion}

During the presented excavations in 2016, the authors of the article obtained important information related to the chronology of settlement in the Central Váh region. New finds of microliths from the site of Sedmerovec-Podjamie most probably confirm the first evidence of Mesolithic settlement in the area of radiolarite sources in the White Carpathians and Central Váh region. With regard to the results of the 2015 investigation (Cheben et. al., in print), we must consider much longer time range in study area, supposedly in the Palaeolithic and Mesolithic, but for sure in the Neolithic, Eneolithic and Bronze Age. The investigation also points to the great potential of the studied region in solving the question of the chipped stone industry raw material use in prehistory or the transition between the late Mesolithic and Early Neolithic.

\section{Acknowledgment}

We would like to thank P. Allard, B. Gehlen, and S. K. Kozlowski for consultation on the chronological classification of lithic industry and to V. Tejbusová for translation of manuscript to English. The study was supported by Project APVV14-0742, The dynamics of use of raw material sources in the Paleolithic and Neolithic in Western Slovakia.

\section{References}

Bárta J. 1965. Slovensko v staršej a strednej dobe kamennej. Bratislava. Broglio A., Kozłowski S. K. 1984. Tipologia ed evoluzione delle industrie mesolitiche di Romagnano III. Preistoria Alpina 19: 93-148.

Cheben I., Illášová L', Hromada J., Ožvoldová L., Pavelčík J. 1995. Eine Oberflächengrube zur Förderung von Radiolarit in Bolešov. Slovenská Archeológia 63:185-203.

Cheben I., Illášová L., Hromada J. 1996. Povrchový prieskum rádiolaritov v Bolešove. AVANS 1994: 98-99.

Cheben I., Cheben M. 2010. Research on Radiolarites of the White Carpathian Klippen Belt. Slovenská archeológia 58: 13-52.

Cheben I., Cheben M., Nemergut A., Soják M. in print. The latest knowledge in use of primary sources of radiolarites in the central Váh region (the microregion of Nemšová-Červený Kameň). In: Budziszewski J., Werra D. H., Woźny M. (eds.), Jacek Lech - special dedicatory volume. Warszawa.

Gehlen B. 2009. Innovationen und Netzwerke. Das Spätmesolithikum vom Forggensee (Südbayern) im Kontext des ausgehenden Mesolithikums und des Altneolithikums in der Südhälfte Europas. Archäologische Informationen 32: 173-185.

Gehlen B. 2010a. Innovationen und Netzwerke. Das Spätmesolithikum vom Forggensee (Südbayern) im Kontext des ausgehenden Mesolithikums und des Altneolithikums in der Südhälfte Europas. Edition Mesolithikum 2. Kerpen-Loogh.

Gehlen B. 2010b. Neolithic transition processes in Southern Europe: The present state of knowledge and its deficiencies in Northern Italy and Southwestern France. In: Gronenborn D., Petrasch J. (eds.), Die Neolithisierung Mitteleuropas. Internationale Tagung, Mainz 24. bis 26. Juni 2005. The Spread of the Neolithic to Central Europe. International Symposium, Mainz 24 June - 26 June 2005. RGZM Tagungen. Mainz, 607-635.

Kaczanowska M., Kozłowski J. K., Wasilewski M. 2015. Chipped, ground and polished stone industries at the early Neolithic settlement of Moravany. In: Kozłowski J. K., Nowak M., Vizdal M. (eds.), Early Farmers of the Eastern Slovak Lowland: The Settlement of the Eastern Linear Pottery Culture at Moravany. Kraków, 163-196.

Kaminská L., Kaczanowska M., Kozłowski J. K. 2008. Košice-Červený rak and the Körös/Eastern Linear transition in the Hornád basin (eastern Slovakia). Přehled výzkumů 49: 83-91.

Kozłowski J. K., Kozłowski S. K. 1984. Le Mésolithique a l'est des Alpes. Preistoria Alpina 19: 37-56.

Kozłowski J. K., Nowak M. 2010. From Körös/Criş to the early Eastern Linear Complex: multidirectional transitions in the north-eastern fringe of the Carpathian Basin. In: Kozłowski J. K., Raczky P. (eds), Neolithization of The Carpathian Basin, Northernmost Distribution of The Starcevo/Koros Culture. Kraków - Budapest, 65-90.

Mello J., et al. 2011. Vysvetlivky ku geologickej mape Stredného Považia 
1:50 000. Bratislava.

Nemergut A., Cheben M., Gregor M. 2012. Lithic raw material use at the Palaeolithic site of Moravany nad Váhom-Dlhá. Anthropologie 50/4: 379-390.

Perrin T., 2009. New perspectives on the Mesolithic/Neolithic transition in northern Italy. In: McCartan S., Schulting R., Warren G., Woodman P. (eds.), Mesolithic horizons, Vol. 2. Oxford: Oxbow Books, 514-519.

Vlkolinská I., Illášová L., Hunka J. 1998. Výsledky prieskumu na trase dial'nice. AVANS 1996: 170-171, 127-279.

Wąs M., 2011. „Janisławickie” i „wstęgowe” koncepcje rdzeniowania wiórowego. Próba konfrontacji technologicznej. Acta Universitatis Lodziensis. Folia Archaeologica 2012/28: 5-23.

Žaár O., Schreiber P., Štec L., Blašková L'. 2013. Nové povrchové nálezy z Bohuníc a Sedmerovca. AVANS 2009: 264-265, 342-346. 